Review

\title{
Overtourism: Between the Right to Travel and Residents' Rights
}

\author{
Dalia Perkumienè and Rasa Pranskūnienè *
}

Faculty of Bioeconomy Development, Vytautas Magnus University Agriculture Academy, Universiteto str. 10, LT-53361 Akademija, Kaunas distr., Lithuania; dalia.perkumiene@vdu.lt

* Correspondence: rasa.pranskuniene@vdu.lt; Tel.: +370-6151-8332

Received: 6 March 2019; Accepted: 1 April 2019; Published: 10 April 2019

\begin{abstract}
Debates on overtourism, as a challenging phenomenon, are becoming more and more active. The purpose of this integrative review paper is to discuss the right to travel and residents' rights in the context of overtourism and sustainable tourism, analyzing different scientific and legal sources. The integrative review analysis shows that overtourism and sustainable tourism are important contexts influencing the changing meaning of the right to travel and the right to live. On the one hand, the overtourism context makes the voices of residents more important to be heard, while on the other hand the sustainable tourism context influences the discussion of the right to travel, asking tourist voices to be considered more important. The results of this integrative review also shows the importance of rethinking the concept of sustainability in tourism as a holistic principle of democracy and as a degrowth movement, and opens the broader discussion for future tourism research development. The problem of overtourism could be solved by striving to develop sustainable tourism goals, thus balancing equality between the right to travel and residents' rights. The presented integrative review paper is a preliminary work; further research is needed in order to find possible concrete solutions for overtourism.
\end{abstract}

Keywords: overtourism; right to travel; residents' rights; sustainable tourism; degrowth

\section{Introduction}

A discussion regarding overtourism in the context of the right to travel and residents' rights is needed, as debates on overtourism, as a challenging phenomenon, are becoming more and more active. Tourism has experienced a rapid expansion and diversification worldwide in recent decades $[1,2]$. Tourism is considered to be the sum of the phenomena and relationships, as noted by Heslinga [2], which arise from the interactions between tourists, business suppliers, host governments, and host communities. Tolkach et al. [3] pointed out that the potential for tension between tourists and residents due to tourist behavior is rising. Nagy [4] argues that further challenges for touristic organizations are arising around achieving acknowledgement by local players. Williams and Lawson [5] (p. 270) have pointed out that "the impact of tourism on host governments and residents has been a growing area of research, as it has become widely recognized that planners and entrepreneurs must take the views of the host community into account if the industry is to be sustainable in the long term" (Allen, Long, Perdue and Kieselbach, 1988; Ap and Crompton, 1998; Belisle and Hoy, 1980; Doxey, 1975; Maddox, 1985; Murphy, 1983, as cited in Williams and Lawson, [5]). Tourism is associated with the processes of globalization, experiencing (as yet) an uncertain trajectory of growth, and generating and distributing its benefits and costs unevenly (Mowforth and Munt, 2015; Gren and Huijbens, 2016, as cited in Margaryan, [6]). This has to be emphasized, as noted by Margaryan [6], because tourism has for a long time (and often still) been uncritically perceived as an alternative to heavy industries, as it is considered light, clean, low-impact, and non-consumptive. The importance of degrowth in tourism 
thinking has now been considered [7-9]. The rights of travelers' and the local population's right to live where they please are important to discuss in the context of overtourism. These rights have been analyzed by different researchers. Juss [10] acknowledges that a fundamental right of travelers' - the freedom of movement-does not entail an automatic right to enter into other states. Dauvergne and Sovereignty [11] have analyzed how the right to free movement confronts the state-based international community. The importance of those rights, legal regulation, and problems were further revealed by Gilbert and Groenendijk et al. [12].

The purpose of this integrative review paper is to discuss the right to travel and residents' rights in the context of overtourism and sustainable tourism, analyzing different scientific and legal sources.

The work of this integrative review is organized as follows: in further sections the materials and methods, results, discussion, and concluding insights are presented. The literature review method-an integrative review-is described in the materials and methods section. The integrative review results are presented in the Results section (the integrated review data is organized under the following themes: the phenomena of overtourism; legal regulation (as well legal cases and conventions) of the rights of individuals to travel and residents' rights in the context of overtourism; and the rights of individuals to travel and residents' rights in the context of sustainable tourism). The Discussion section discusses overtourism and sustainable tourism as contexts, and this integrative review finishes with some concluding insights.

\section{Materials and Methods}

Literature reviews are conducted differently for various audiences and for different purposes [13]. Torraco [13] explained that most integrative literature reviews address two common types of topics-mature topics, or new, emerging topics. This integrative review paper seeks to undertake an interdisciplinary discussion about the right to travel and residents' rights in the context of overtourism and sustainable tourism. As overtourism is a new and emerging topic, it seemed important for this research to use the integrative review method. For this paper, the integrative review approach outlined by Whittemore and Knafl [14] was adopted: "The integrative review method is an approach that allows for the inclusion of diverse methodologies, and contributes to the presentation of varied perspectives on a phenomenon of concern" [14] (p. 547). Additionally, Whittemore and Knafl [14] noted that integrative reviews seek to define concepts, review theories, review evidence, and analyze methodological issues of a specific topic. For this review, the following research methods are also utilized: analytical analysis of scientific literature, abstraction method, analysis of documents and cases of law, and logical and systematic legal analysis. The aim is not only to analyze general laws, judicial requests, and scientific opinions, but also to interpret the philosophical and traditional aspects that are associated with the right to travel and the rights of residents. We have chosen to look at the special juxtaposition or tension between the right to travel and residents' rights, so the international cases will focus on issues in that particular field.

The review includes five stages [14]: identification of the problem, search of the literature, evaluation of the data, analysis of the data, and presentation (Table 1). 
Table 1. Stages of the review.

\begin{tabular}{|c|c|c|}
\hline No & Stage of Review & Description of Review Stages \\
\hline 1. & Problem identification & $\begin{array}{l}\text { Theoretical and empirical discussions in the past few years about overtourism } \\
\text { as a topic showed the importance of interdisciplinary research, and the } \\
\text { importance of discussing the right to travel and residents' rights. }\end{array}$ \\
\hline 2. & Literature search & $\begin{array}{l}\text { With a specific focus on overtourism, the literature was searched for } \\
\text { "overtourism". There were only a few databases and open libraries where } \\
\text { articles about overtourism were found: DOAJ (Directory of Open Access } \\
\text { Journals), } 5 \text { articles; SCIENCERESEARCH, } 34 \text { articles (including media } \\
\text { articles); IDEAS/RePEc, } 5 \text { articles; World Library of Science, } 6 \text { articles. No } \\
\text { articles about the overtourism topic were found in the databases and open } \\
\text { libraries: The OAPEN Library, OpenDOAR, Electronic Journals Library, } \\
\text { WorldWideScience.org, and others. The literature was also searched for the } \\
\text { right to travel and residents' rights, sustainability and degrowth. }\end{array}$ \\
\hline 3. & Data evaluation & $\begin{array}{l}\text { Theoretical and empirical literature in overtourism, sustainability, degrowth, } \\
\text { and legal cases discussing the right to travel and residents' rights. }\end{array}$ \\
\hline 4. & Data analysis & $\begin{array}{l}\text { The theoretical and empirical literature in overtourism, sustainability, } \\
\text { degrowth and legal cases discussing the right to travel and residents' rights } \\
\text { were analyzed, discussing the topics: sustainability and tourism, degrowth, } \\
\text { tourists and residents, overtourism, media cases, and legal cases and } \\
\text { conventions. }\end{array}$ \\
\hline 5. & Presentation & $\begin{array}{l}\text { The integrative review was presented in the results chapter (the integrated } \\
\text { review data was organized under the following themes: the phenomena of } \\
\text { overtourism; legal regulation of the rights of individuals to travel and residents' } \\
\text { rights in the context of overtourism; the rights of individuals to travel and } \\
\text { residents' rights in the context of sustainable tourism), and in the discussions } \\
\text { chapter the conceptual figure was presented (Figure 1). Overtourism and } \\
\text { sustainable tourism contexts in changing the meaning between the right to } \\
\text { travel and right to live. }\end{array}$ \\
\hline
\end{tabular}

Due to the small number of research articles found on the overtourism research topic, it was decided not to apply criteria to retain or reject articles from the review. Instead, there were some criteria applied to their selection: for the integrative review, the articles discussing the concept of overtourism and revealing possible future solutions and trends in the interdisciplinary perspective of overtourism (overtourism phenomena, legal cases, overtourism cases, sustainability, and degrowth) were focused on.

\section{Results}

Articles selected for the analysis are presented in Table 2. The sample of the integrated review consisted of 29 studies ( 25 research papers and 4 media cases). As can be seen in Table 2, the main sources for the review are new articles (2017-2019).

As previously mentioned, articles discussing the topics of sustainability and tourism, degrowth, tourists and residents, overtourism, and media cases (Table 2), as well legal cases and conventions (Table 3), were the focus of the review. The integrated review data was organized under the following themes: the phenomena of overtourism; legal regulation of the rights of individuals to travel and residents' rights in the context of overtourism; and the rights of individuals to travel and residents' rights in the context of sustainable tourism. 
Table 2. Description of papers, selected for review analysis.

\begin{tabular}{|c|c|c|c|}
\hline Authors & Year & Journal/Book & Keywords \\
\hline & & Sustainability and tourism & \\
\hline Alvarez-Sousa [15] & 2018 & Sustainability & $\begin{array}{l}\text { Tourism sustainability, carrying capacity, anti-tourism, tourism-phobia, interest groups, } \\
\text { sustainable planning, grounded theory }\end{array}$ \\
\hline Gössling, Scott, Hall [16] & 2018 & Journal of Sustainable Tourism & $\begin{array}{l}\text { Climate change, destination management, length of stay, optimization, transport capacity } \\
\text { greenhouse gas emissions }\end{array}$ \\
\hline Heslinga [2] & 2018 & University of Groningen & Synergetic interactions, policy, tourism landscape, social-ecological systems \\
\hline Ram, Hall [7] & 2018 & International Journal of Tourism Cities & Walkability, cities, destinations, accessibility, tourism walking \\
\hline Margaryan [6] & 2017 & Östersund: Mid Sweden University & Tourism, tourism setting, nature resources, commercialization, Sweden \\
\hline Nagy [4] & 2016 & Gödöllő: Szent István University & Tourism, environment, impact, regions, spatial economy, Hungary \\
\hline \multirow[t]{2}{*}{ Davidson, Kellett, Wilson, Pullen [17] } & 2012 & Local Environment & $\begin{array}{l}\text { Urban sustainability, assessment, indicators, sustainability, social democracy, thematic } \\
\text { approach }\end{array}$ \\
\hline & & Degrowth & \\
\hline Buhr, Isaksson, Hagbert [9] & 2018 & Sustainability & Degrowth, local growth, local policy, interpretations, planning, radical sustainability \\
\hline Andriotis [8] & 2014 & $\begin{array}{l}\text { Thematic Tourism in a Global } \\
\text { Environment }\end{array}$ & Development, degrowth paradigm, antimaterialism \\
\hline Hall [18] & 2010 & Tourism Recreation Research & $\begin{array}{l}\text { Sustainable tourism, global environmental change, epistemic community, ecological } \\
\text { economics; degrowth; steady-state tourism }\end{array}$ \\
\hline Hall [19] & 2009 & $\begin{array}{l}\text { An International Journal of Tourism and } \\
\text { Hospitality Research }\end{array}$ & $\begin{array}{l}\text { Degrowth, decroissance, economism, steady-state tourism, sustainable consumption, } \\
\text { sustainable tourism, slow tourism }\end{array}$ \\
\hline \multirow[t]{2}{*}{ Flipo, Schneider (editors) [20] } & 2008 & Conference proceedings & Degrowth, growth, sustainable development, democracy, social equity, ecology \\
\hline & & Tourists and Residents & \\
\hline Armenski, Pavluković, Pejović, Lukić, Djurdjev [21] & 2011 & Polish Sociological Review & Tourists-residents interaction, social demography, Serbia \\
\hline Brokaj [22] & 2014 & European Scientific Journal & Sustainable tourism, local government, destination, stakeholder \\
\hline Williams, Lawson [5] & 2001 & Annals of Tourism Research & Tourism, host perceptions, New Zealand, community issues \\
\hline Kim [23] & 2018 & Sustainability & Contact hypothesis, reality, intercultural exchange, local encounter \\
\hline
\end{tabular}


Table 2. Cont.

\begin{tabular}{|c|c|c|c|}
\hline Authors & Year & Journal/Book & Keywords \\
\hline & & Overtourism & \\
\hline Oklevik, Gössling, Hall, Steen Jens, Grøtte, McCabe [24] & 2019 & Journal of Sustainable Tourism & $\begin{array}{l}\text { AirBnB, climate change, destination management, optimization, overtourism, Fjord } \\
\text { Norway }\end{array}$ \\
\hline $\begin{array}{l}\text { Séraphina, Zamanb, Olverc, Bourliataux-Lajoinied, } \\
\text { Dosquete [25] }\end{array}$ & 2019 & $\begin{array}{l}\text { Journal of Hospitality and Tourism } \\
\text { Management }\end{array}$ & Destination branding, repositioning, overtourism \\
\hline Milano [26] & 2018 & Pasos Rev. & Overtourism, tourismphobia, social problem, resident-philia, debate \\
\hline Blanco-Romero, Blázquez-Salom, Cànoves [27] & 2018 & Sustainability & $\begin{array}{l}\text { City, tourism, crisis, tourist housing, political economy of tourism, social movements, } \\
\text { Barcelona }\end{array}$ \\
\hline Martín, Martínez, Fernández [28] & 2018 & Sustainability & $\begin{array}{l}\text { Social sustainability, tourism, sharing economy, economic dependence, economic impacts, } \\
\text { overtourism, anti-tourism movements }\end{array}$ \\
\hline Postma, Schmuecker [29] & 2017 & Journal of Tourism Futures & $\begin{array}{l}\text { City tourism, conflict mechanisms, host-guest relations, impacts, overtourism, tourism } \\
\text { impact studies, visitor management }\end{array}$ \\
\hline Muler-Gonzalez, Coromina, Galí [30] & 2018 & Tourism Review & $\begin{array}{l}\text { Residents, social carrying capacity, social exchange theory, sustainable tourism, heritage } \\
\text { towns, Besalú, Catalonia, Spain }\end{array}$ \\
\hline \multirow[t]{2}{*}{ Papathanassis [31] } & 2017 & Economic Sciences Series & Tourism, antagonism, destination, sustainability, over-tourism, externalities \\
\hline & & Media cases & Headline \\
\hline Bonnie [32] & 2018 & The week & Why is there no right to live where you please? \\
\hline Kim [33] & 2017 & The Telegraph & $\begin{array}{l}\text { Iceland now has seven times more tourists than locals-but which country is most } \\
\text { overrun with visitors? }\end{array}$ \\
\hline Mack [34] & 2017 & Responsible travel & Responsible travel. Who is responsible for overtourism? \\
\hline Scott [35] & 2018 & uncorneredmarket.com & How Social Media Influencers Can Use Their Power to Combat Overtourism \\
\hline
\end{tabular}




\subsection{The Phenomena of Overtourism}

Overtourism is, therefore, not a new problem. According to Koens et al. [36], the term 'overtourism' emerged from the media without a more serious theoretical grounding in the last few years. The concept of overtourism has been discussed in recent years as one of the most debatable issues related to tourism in the media and, increasingly, in academia [36]. It seems that, as a concept, overtourism has emerged rapidly and the terms of 'overtourism' or 'tourismphobia' have made headlines in recent times [1]. This problem is not particular to Spain; Martin et al. [28] noticed that conflicts related to excessive tourism experience were also being seen in other European cities, like Amsterdam, London, Paris, Berlin, Venice, Rome, and Florence. Erschbamer et al. [37] pointed out that although the phenomenon of overtourism has appeared in the press in the last few months, and the use of it in conferences and discussions is increasing, in some tourist destinations the perception of 'too much' is not new. In 1980, Erschbamer et al. [37] noted that the magazine GEO had raised a critical question: "How many tourists per hectare of beach?", and the concept of "carrying capacity" was discussed, which was subsequently also explored later-such as in the 1990s, by various tourism researchers, to shed light upon the maximum destination load. Researchers such as Canastrelli and Costa [38], Page [39], and Borg et al. [40] explored problems derived from the tourist saturation of cities. Borg et al. [40] discussed the negative side of tourism in Venice, such as the pollution of the environment, more intensified vandalism and crime, parking problems, and more. However, nowadays a very limited set of scientific sources analyzing overtourism (or tourismphobia) is available and many works are exploratory in nature. Some are related to tourism in the urban or rural context, and also available literature is discussion of the legal and political aspects related to excessive tourism growth [36,41-47]. Postma [47] argues that overtourism is not the same as mass tourism; although the growing number of tourists is the cause of overtourism, some areas are able to cope with large tourist numbers. The author [47] points out that the overtourism phenomena is more related to perceptible tourism encounters, environmental changes, and violations of human life. In the current climate, as Oklevik et al. [24] noted - and with widespread media-reporting on 'overtourism', overcrowding, and anti-tourist sentiment (e.g., Skift, 2017; Independent, 2017; Telegraph, 2018)—destination marketing organizations, particularly in Europe, have started open and critical discussions about the desirability of further developing tourism growth perspectives. Overtourism can be understood as destinations or places where people (visitors or locals, guests, or hosts) believe there are too many visitors, and consequently they feel the quality of the experience, at the same time as the quality of life in the region, have become quite poor $[48,49]$.

It seems important to understand the overtourism phenomena through discussing the right to travel and right to live.

The right to travel, or individuals' mobility rights or freedom of movement, is a human rights concept encompassing the right of persons' to travel from place to place within the territory of a country [15,50], and to leave the country and return to it. The right to travel includes not only visiting different places, but also changing the place where the individual resides or works $[15,50]$. Freedom of movement is a part of human history $[15,50]$. The right to travel, or individuals' mobility rights, are recognized in international legal human rights instruments. However, according to Satvinder and Juss [10], the right of free movement cannot be interpreted as an automatic right of access to other countries. In this case, the mentioned right is in conflict with the international community of the state, where there is a greater concern about the types of migration for selected people [10]. 
Table 3. Description of legal acts.

\begin{tabular}{|c|c|c|}
\hline Year & Legal Cases and Conventions & Keywords \\
\hline $\begin{array}{l}1958 \\
{[51]} \\
2002 \\
{[52]}\end{array}$ & $\begin{array}{l}\text { Kent v. Dulles } \\
\text { No. } 357 \text { U.S. } 116 \\
\text { Loubna El Ghar v. Socialist People's Libyan Arab } \\
\text { Jamahiriya } \\
\text { No. } 1107 / 2002\end{array}$ & $\begin{array}{l}\text { Right to travel, liberty, restrictions } \\
\text { Right to travel, restrictions, travel document, } \\
\text { free movement of persons }\end{array}$ \\
\hline $\begin{array}{l}1980 \\
{[53]} \\
2005 \\
{[54]} \\
2011 \\
{[55]}\end{array}$ & $\begin{array}{l}\text { Samuel Lichtensztejn v. Uruguay } \\
\text { No. } 77 / 1980 \\
\text { Timishev v. Russia } \\
\text { No. } 55762 / 00 \\
\text { Karpacheva and Karpachev v. Russia } \\
\text { No. } 34861 / 04\end{array}$ & $\begin{array}{l}\text { Right to travel, restrictions, citizen's passport, } \\
\text { free movement of persons } \\
\text { Right to travel, restrictions, travel document, } \\
\text { free movement of persons } \\
\text { Right to travel, restrictions, travel document, } \\
\text { free movement of persons }\end{array}$ \\
\hline $\begin{array}{l}1992 \\
{[56]} \\
2012 \\
{[57]}\end{array}$ & $\begin{array}{l}\text { Lauri Peltonen v. Finland } \\
\text { No. } 492 / 1992 \\
\text { Stamose v. Bulgaria } \\
\text { No. } 29713 / 05\end{array}$ & $\begin{array}{l}\text { Right to travel, right to leave, passport, free } \\
\text { movement of persons } \\
\text { Right to travel, travel ban, passport, free } \\
\text { movement of persons, forced deportation }\end{array}$ \\
\hline $\begin{array}{l}1994 \\
{[58]}\end{array}$ & $\begin{array}{l}\text { Coeriel and Aurik v. The Netherlands } \\
\text { No. } 453 / 1991\end{array}$ & Privacy, right to travel, identity, person's life \\
\hline $\begin{array}{l}1992 \\
{[59]}\end{array}$ & $\begin{array}{l}\text { Niemitz v. Germany } \\
\text { No. } 13710 / 88\end{array}$ & $\begin{array}{l}\text { Private life, right to travel, identity, person's } \\
\text { life, right to develop relationships with others }\end{array}$ \\
\hline $\begin{array}{l}1989 / 1990 \\
{[60]}\end{array}$ & Convention on the Rights of the Child & $\begin{array}{l}\text { Rights of the child, right to travel, travel ban, } \\
\text { passport, free movement of persons. }\end{array}$ \\
\hline $\begin{array}{l}1976 \\
{[61]}\end{array}$ & $\begin{array}{l}\text { International Covenant on Civil and Political Rights } \\
\text { (ICCPR) }\end{array}$ & $\begin{array}{l}\text { Civil and political rights, right to travel, free } \\
\text { movement of persons }\end{array}$ \\
\hline $\begin{array}{l}1990 \\
{[62]}\end{array}$ & $\begin{array}{l}\text { International Convention on the Protection of the } \\
\text { Rights of All Migrant Workers and Members of Their } \\
\text { Families (ICPMW) }\end{array}$ & $\begin{array}{l}\text { Migration, migrant workers, right to travel, } \\
\text { free movement of persons }\end{array}$ \\
\hline $\begin{array}{l}2006 \\
{[63]}\end{array}$ & Convention on the Rights of Persons with Disabilities & $\begin{array}{l}\text { The rights of persons with disabilities, right } \\
\text { to travel, free movement of persons }\end{array}$ \\
\hline
\end{tabular}

When discussing the right to live, Alvarez-Sousa [15] points out that residents disagree with traditional businesses because of problems such as sun loungers and umbrellas on the beach for tourists, and cafeteria tables released to the public. These issues lead to more diverse political confrontation, participants of which may have different positions regarding the plight of residents and businesses. As residents are the cultural agents and the social group in which tourism operates, they play an important role in the development of sustainable tourism. As noted by Muler-Gonzalez et al. [30], tourism providers could benefit from a deeper understanding of locals' attitudes to tourism. It is interesting to point out the sharing economy experiences overtourism as well. Residents and entrepreneurs of the sharing economy disagree because of the way the latter distort the habitat, as discussed by Alvarez-Sousa [15]. These companies advertise apartments for tourists to use which are not licensed for tourism activities, and this divides residents, as some support the business of these companies (Airbnb, Homeaway, etc.) and have no obligation to participate and rent their home, some rent them illegally, while others do not want anything to do with renting their home, and protest such activities.

To sum up, almost all the definitions of overtourism point out that overtourism is characterized by an excessive number of visitors, which affects the quality of the region. Overtourism is also related to violations of human life quality assurance (both travelers and locals), and environmental changes.

\subsection{Legal Regulation of the Rights of Individuals to Travel and Residents' Rights in the Context of Overtourism}

In order to determine the rights of travelers and locals in the context of overtourism, we should carefully analyze these concepts. This integrative review discusses the travelers' and locals' rights in general; at this stage of the research it is not intended to analyze the rights of different types of travelers. On the one hand, we briefly analyze the rights of travelers who are traveling for entertainment or consumption and, on the other hand, we deepen the understanding about the rights of locals and 
people who have changed their place of the residence. It also seems important to point out that, in order to review legal regulations in general, it is not intended that this work classify legal norms, but rather we discuss some examples of legal cases and conventions in this particular field.

The legal cases and conventions selected for analysis are presented in Table 3. As can be seen in Table 3, the cases under review are from 1958-2012. This choice of authors was through the selection of classical and typical cases related to this article.

The right to free travel across the country is an essential aspect of our emancipated society, which is retained by citizens [34]. The right to free movement applies to everyone. Any person has the right to leave his or her country. The right to freedom of movement is shrined in different international legal documents.

The right to free movement is established in the main legal document of the Republic of Lithuania. Under Article 32 of Lithuanian Republic Constitution, citizens of Lithuania may freely move and choose their place of residence [64].

One of the most important international legal documents in this sphere is the Universal Declaration of Human Rights. Under Article 13 of this declaration, everyone has the right to free movement and residence within the borders of a country. Everyone is also guaranteed the right to leave any country, and to return to his country [65].

The individuals' mobility rights are also enshrined in Article 12 of the ICCPR. Under this article, everyone has the right to liberty of movement and freedom of choosing their residence [61]. Under Article 10 of the Convention on the Rights of the Child, a child whose parents reside in different states has the right to maintain and communicate directly with both parents [60]. In the International Convention ICPMW is expressed the right to free movement, and in Articles 5, 8, and 39 is highlighted that migrants and their family members are free to leave any country, including their country of origin [62]. The right to free movement is also contained in Article 12 of the African Charter on Human and Peoples' Rights. Under this article, anyone shall have the right to free movement provided he abides by the law [62].

The right to free movement also contains the Convention on the Rights of Persons with Disabilities. This right is expressed in Articles 9 and 18. Article 9 states that the appropriate measures must be taken to ensure that persons with disabilities have equal access to the physical environment, to transport, and to information and communications. Article 18 declares that States Parties recognize the rights of persons with disabilities to freely choose their place of residence and nationality, on an equal basis with others, and also the right of persons with disabilities to move freely [63].

The importance of the right to free movement becomes clear only when a person is actually faced with a possible loss of law. The fundamental right is inalienable; this is the "implicit concept of freedom" [66]. In cases when the government restricts this right, the courts strictly check the laws that may conflict with the fundamental right. To continue with such strict control, this law must pass a two-part test: first, it must be based on a legitimate interest of the state, and secondly, it must be narrowly adapted to achieve this interest [67].

The Supreme Court of the USA, in the case of Kent v. Dulles, stated that the right of free movement is a part of "liberty", and that this right may not be restricted or eliminated [51].

With regard to the free movement of persons and their right to travel, and the restrictions and constraints of these rights, it is important to provide examples of court decisions. For example, in the Loubna El Ghar v. Socialist People's Libyan Arab Jamahiriya case, a resident of Morocco with Libyan nationality had applied for a Libyan passport at the Libyan Consulate [52]. Libyan authorities, over almost three years after this person's application, informed her that she could only be given a travel document, a "laissez-passer", to return to Libya. This decision of Libyan authorities was made without any explanation. According to the HRC (Human Rights Committee) the "laissez-passer", in this particular and in all other cases, cannot be considered as an alternative to the current Libyan passport which gives the person the opportunity to travel abroad [52]. It can be noted that this incorrect 
judgment in this particular case, misinterpreting the instructions of the Human Rights Committee, also confirms restrictions on the free movement of persons and the right to travel.

Another similar case related to restrictions of a person's right to travel and to free movement is the Samuel Lichtensztejn v. Uruguay case. The applicant was a Uruguayan citizen, a former rector of the University of Economics of the Republic of Uruguay, and a dean of the Faculty of Economics and Administration, but residing in Mexico at the time of the application [53]. The applicant from Uruguay moved to Mexico due to the intervention of the Uruguayan military in his professional and personal life [53]. The Uruguayan authorities in Mexico refused to renew their citizen's passport, and did not explain their decision. The applicant interpreted such a situation as the Uruguayan authorities, due to his political dissent, restricting his academic autonomy and independence in Uruguay [53]. This case, like the previous, opens and at the same time confirms legal problems and gaps in the area of the human right to free movement.

The right of people to travel and to move freely may also be based on an individual's ethnic origin, in violation of Article 14 of the Convention [54] or gross violations of the rule of law [48].

In another of our analyzed cases, Lauri Peltonen v. Finland, Finland violated Lauri Peltonen's rights to free movement and right to leave by refusing to issue a passport, thereby limiting the possibility of leaving, because he did not complete compulsory military service [56].

The right to travel may also be violated in the case of forced deportation. For example, on 27 November 2012, the Strasbourg Court ruled on Stamose v. Bulgaria [57]. In 2003, a Bulgarian citizen, Stamose, was sent from the USA to Bulgaria. Due to a forced return to Bulgaria, the Bulgarian authorities imposed a double travel ban on him, inter alia in the letter from the US Embassy [57]. In this way, he was completely restricted from traveling to other countries.

When we discuss the rights of local people or people moving to change their place of residence in the context of overtourism, it should be mentioned that, in the authors' opinion, the most important rights in such situations are the rights to life and rights to private life.

A person's right to privacy is protected by Article 8 of the Human Rights Act. Under this article, the personal and family life of every person must be private [65]. It means that a person has the right to prevent his private life from interfering with his wider life, including illegal care and illegal entry and eviction which does not follow the proper process.

Our privacy is also protected in the International Covenant on Civil and Political Rights, as under Article 17 of the International Covenant on Civil and Political Rights it is stated that there cannot be any unlawful interference in a person's and his family's privacy, home, or correspondence [61]. The main components in this article are the 'family', 'home', and 'correspondence', leaving the definition of privacy itself rather open, although this has been clearly stated in the Coeriel and Aurik v. the Netherlands [58] case. In this case, it was stated that privacy means a personal life where he or she can freely express their identity, whether it be in relationships with others or alone. In another, the Niemitz v. Germany case [59], the European Court established that respect for private life encompasses a certain right to develop relationships with others.

When we talk about a fundamental right to life, we can also raise the question: why is there not a fundamental human right to live where you want? The rights of the local population to live where they want is affected in places where there is a large tourist stream, and locals are confronted with the consequences of overtourism. The right to live where you please is closely related to the concept of freedom of movement, but freedom of movement is often more concerned with travel than residence. When we discuss residents' rights in the context of overtourism, we also should mention the right to the place of the locals, or people moving to change their place of residence. It is in this sense already long recognized-for example by American courts, and protected by law in America-in the form of our right to unrestricted movement between the states and travel abroad with a passport or a temporary residence permit [32]. Bodirsky criticizes the perspective that creates a binary between urban residents who exercises a proper use of the urban space, and those who express urban space to 
realize the value of the exchange [68]. Darcy and Roger emphasize the importance of the right to a place. They argue that the right for residents to participate in place-making should be protected [69].

Another very important right related to the fundamental human rights to life and to residence is a person's everyday right to carry out their daily life activities. It can be noted that in an overtourism context, locals' rights to do so are limited.

This right is closely related to a collective right called the right to the city. The existence and importance of the city right is confirmed by the diverse social movements that are currently taking place throughout the world, demanding city rights as their goal. Urban movements are associated with the city and city policies that reflect the urban environment's problems, needs, and lifestyles [70]. The right to the city also expresses the need to integrate objectionable groups, such as the homeless, persecuted, hungry or poor, into the existing system [56,70]. The aim of the right to the city is to adopt policies and legislation that combine urban development with social justice [70]. The right to the city gives all residents of the city the opportunity to influence the future of their city, and the right to live in the neighborhood where they live [71].

Here, the question of equity arises. Local residents (as well people who have changed their place of residence) who live under an equitable situation necessarily concentrate on social justice. Equity has an intergenerational aspect, which is a cause for concern in terms of the allocation of resources between current and future generations [70].

In summarizing the relationship between the rights of travelers and the local population's right to live where they please, it is closely related to the concept of freedom of movement in the context of overtourism. As mentioned before, the right to free movement is more concerned with travel than residence. It can also be noted that the rights of travelers are clearer, better regulated, and better protected and the interpretation of the rights of the local population, which are broad and not so effectively expressed. The cases analyzed above highlight the problems that arise in the area of the free movement. In these cases, the courts misinterpreted national and international legal acts based on social, economic, and political motives. It is important to note that the rights of travelers, who are tourists moving for entertainment and consumption purposes, are not equivalent to the rights of those people moving to change their place of residence and people already living in the tourist destination. It is also important to consider that those people moving to change their place of residence are becoming residents, and in this way their status changes so that their original rights are replaced by others, and vice versa.

\subsection{Rights of Individuals to Travel and Residents' Rights in the Context of Sustainable Tourism}

Sustainability as holistic principle of democracy-Sustainability is necessarily a social democratic approach, based on a clear set of values such as social justice, equity, and environmental quality [17]. "Political freedom is presupposed in any debate on sustainable tourism development, as justice and democracy underlie the idea of sustainability" [17] (p. 896). As the concept of sustainability has been used at least for the last few decades, Hall [18] reminds us that, since the late 1980s, the concept of sustainable tourism has been at the centre of tourism academic discourse. Postma et al. [72] argue that the concept of sustainable development dates back to 1987. In 1972, the alarming report "Limits to Growth", as other authors [72] have noticed, was released by the Club of Rome. The report was concerned about the continuing negative social and environmental outcomes of economic growth. However, what about the current sustainability challenges and opportunities for the future? The development of sustainable tourism should be in line with the needs of existing tourists and host regions seeking to open up opportunities for the future [73]. It seems important to look at present day sustainable tourism concepts. UNWTO [1] defines sustainable tourism as tourism "that takes full account of the current and future economic, social and environmental impacts, addressing the needs of visitors, the industry, the environment and host communities". Swarbrooke [74] (p. 41) noted that "sustainable tourism is, perhaps, an impossible dream, and the best we can hope for is to develop more sustainable forms of tourism". It is important to add to this discussion the ideas of Hall [18], who 
pointed out that without a fundamental or paradigmatic change in thinking and action on tourism sustainability, it will continue to be unsustainable. Hall [18] noted the importance of change to the maintenance of natural capital and steady-state thinking as well.

The importance of the social system in the interactions of tourists and locals-Alvarez-Sousa [15] notes that tourism should be understood within the social system, as the interaction of tourists and local residents in the provision of services is a facet of the practical problems they face. However, tourism cannot function beyond the boundaries of politics and the influence of the media. Alvarez-Sousa [15] presented the relationships among all parts of the system. Brokaj [22] notes that sustainable tourism is not an exclusive or special form of tourism, and all forms of tourism should strive to be more sustainable. Several policy areas need to be integrated to ensure effective planning and development of sustainable tourism, taking into account the various natural, cultural, and human resources. Proper implementation of the principles of sustainable tourism strategy and rational legal regulation are essential for successfully attracting and tolerating local people; this is one of the key elements for sustainable tourism development [22]. Armenski et al. [21] argue that tourism can be sustainable if developed and managed considering both tourists and local communities [21]. Postma et al. [61] point out that this is not enough for the sustainability of the tourism industry. They note that the impact of tourism on the local population is not by itself positive. Sustainable tourism practices can only be attained when the holistic principle of sustainability is understood and integrated into the strategic planning of the industry [22]. Sustainability of a tourism product mainly depends on the experience of tourists [22].

Sustainability as degrowth-The first international conference on economic degrowth for ecological sustainability and social equity [20] was held in Paris (2008), followed by conferences in Barcelona (2010), Berlin (2011), Montreal (2012), Venice (2012), Leipzig (2014), Budapest (2016), Malmö (2018), Mexico (2018), and Brussells (2018). Büscher and Fletcher [75] believe that tourism has to be part of a broader degrowth movement. So, what could the degrowth movement suggestions be for tourism? Bourdeau and Berthelot [69], discussing tourism and decay, point out that apart from decreasing tourism, a vast field is open in the renewal of the imagery of the relationship between "here" and "elsewhere", as such a perspective calls for a number of discussions and reflections. Hall [18] suggests thinking about the four ' $R$ 's of steady-state tourism consumption: reduce, reuse, recycle, and regulate. Additionally, Hall [19] notes that the slow consumption approach is closely linked to the concept of 'decroissance' or 'degrowth'. Andriotis [8] argues that degrowth reorients the current unsustainable and inappropriate approach to tourism, turning it into a smaller economy with less production and consumption. As a philosophical concept and movement, Andriotis [8] points out that degrowth is revolutionary and anticapitalist; it is focused on sustainable change and results from an interest in locality and place, small and medium-sized enterprises, job creation and reduction of working hours, ecology and quality of life, reduction of tourism activities, carbon reduction in the transport sector, a change in production and consumption patterns, and the high priority of the travel experience. In the context of sustainable tourism, we should definitely talk about balancing the right to travel and the right to live. Gössling et al. [16] note that it is time to re-think models of destination growth and sustainability, and suggest we should all together accept the terms of sustainable design. Ram and Hall [7] note that walkable places are regarded as preferable for locals and tourists alike. To seek these goals, we should discuss challenges such as the challenge for equal rights in the context of sustainable tourism, and conflict between residents and tourists.

Challenges for equal rights in the context of sustainable tourism and conflict between residents and tourists-Nowadays, more and more visitors visit residential areas. Kim [23] has noticed that this can increase real estate prices and has additional social costs. Furthermore, locals may feel annoyed at tourists suddenly arriving and partying in their quiet neighbourhood. At this point, the question arises as to whether the creation of the local tourist experiences definitely has only a positive perspective. Thus, Kim's [33] study's findings reveal possible conflict between visitors and locals. Kim [23] discusses the importance of proper resolutions for this issue. Otherwise, the sustainability 
of the tourism model "living like a local" becomes questionable, despite the virtue of every society being hospitable to visitors. Kim [23] also notes that it becomes really challenging to deal with too many visitors who may trouble the locals' lives. They suggest that policy makers seriously consider how to reconcile the quality of life of both the locals and the tourists with local experiences. Canziani and Francioni (2013, citing in Waller, [76]) emphasize that, when tourists and residents are faced with the role of consumer/service provider in the professional environment, tourists treat the residents as occupational workers rather than as other ordinary residents. Another doubt regarding the sharing economy arises here as well. The rise of the sharing economy, as Postma and Schmuecker [29] note, has recently added an additional dimension to the debate. These authors [29] point out that over the past few years the media have informed on various incidents from the residents' side. Tourists are confronted with residents, as Alvarez-Sousa [15] notes, because of their disorderly behaviour and non-compliance with social norms; they are also opposed to workers, groups of specialized workers, and conventional entrepreneurs who are trying to provide services to employees, and entrepreneurs who work beyond the boundaries of legality, using cheaper and permitted services. Alvarez-Sousa [15] points out that this causes confrontation with tourism operators and local authorities who are trying to comply with the guidelines.

\section{Discussion: Overtourism and Sustainable Tourism as Contexts}

Discussing overtourism and sustainable tourism as contexts between the right to travel and the right to live raises the changing meaning of tourists and locals (Figure 1). As Kim [33] notes, in Iceland at the present time there are seven times more tourists than locals. Scott [35] asks the question: Can social media tools influence and change travelers' decisions to achieve positive effects? Mack [34] points out that we are all responsible for overtourism. We all need to own it. The same expression of dissatisfaction could be equated with a 'slow train', but it should be noted that this train itself chooses a speed, and allows those around it to hear its roar as well.

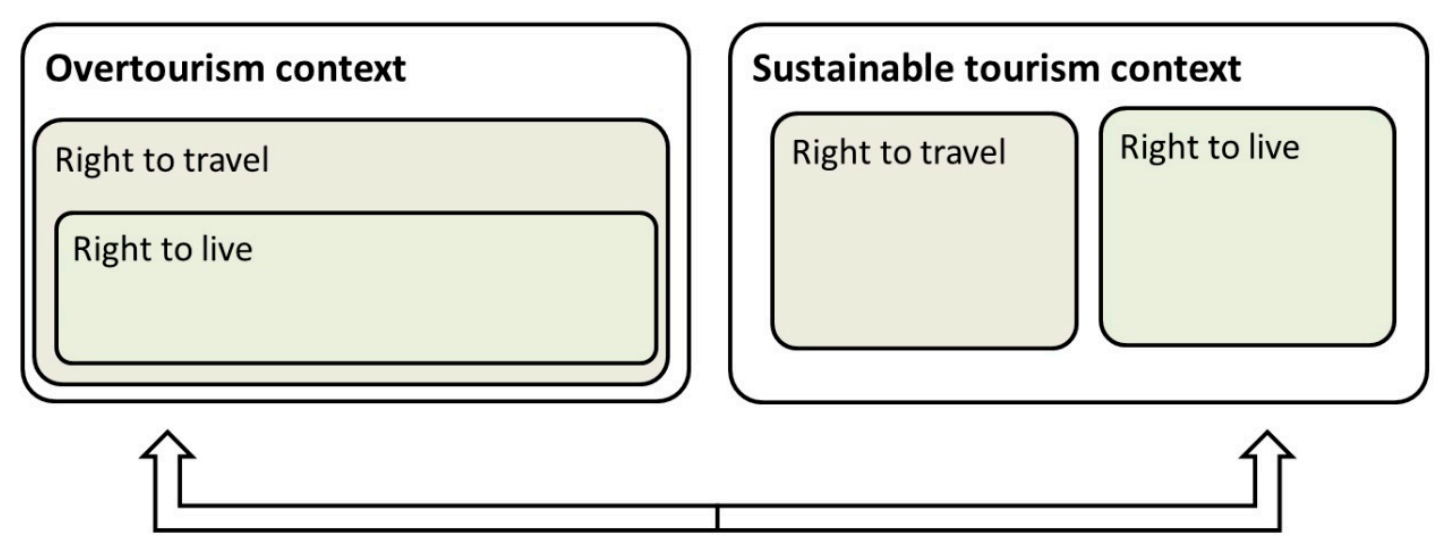

Figure 1. Overtourism and sustainable tourism contexts. Between the right to travel and the right to live.

Figure 1 emphasizes that the problem of overtourism can be solved only by working together and striving to develop sustainable tourism goals, thus balancing the right to travel and the right to live. Postma and Schmuecker [29] note that tourism is subject to massive growth. The authors [29] point out that the World Tourism Monitor IPK states that city tourism is the fastest growing market segment in tourism (IPK International, 2016, citing Postma and Schmuecker [29]). Are there the effects from being the fastest growing market segment for city tourism? The authors [29] also point out the effects (direct and indirect) of this increase in the number of visitors, causing an increase in annoyance among residents. Postma and Schmuecker [29] argue that this could lead to conflict situations between tourism services providers, travelers, and locals. Naturally, the question arises here regarding whether we still have to think about growth. Maybe there are degrowth solutions in tourism as well? As a 
consequence, Andriotis [8] points out that degrowth tourism allows the creation of net benefits for local residents and community participation, in turn allowing increased control of resources for groups that are not included in the decision-making processes. Buhr et al. [9] argue that both degrowth and sustainability focus on the environmental crisis and social aspects, however degrowth ideas are very different from basic sustainability research, clearly criticizing the key prerequisites for a dominant economic paradigm. Kallis [77] notes that sustainable degrowth is not just a structuring concept. The author points out the degrowth, as a political project, offers a new story and slogan for a social coalition. Additionally, Kallis [77] argues that this project seeks to construct a society living better with less. Andriotis $[8,78]$ notes the importance of the degrowth movement's guiding philosophy, which is directed towards sustainable change, contributing to a tourism society of degrowth. Examples of future research in the area of overtourism, as Séraphina et al. [25] describe, could include: the political consequences of overtourism (the strategy that will be implemented by political leaders to ensure the happiness of their citizens and to maintain the income of the tourism sector); the romanticized view of some destinations (the difference between a tempting destination and reality); and the experience for tourists visiting overcrowded places (escapist or authentic experience). As Blanco-Romero et al. [26] point out, housing being used for tourist accommodation is one of the new frontiers of tourist business. Therefore, Blanco-Romero et al. [26] note the marking of the environmental border between local residents and tourists, including tourist and urban planning as well as management, could be the way to solve this problem. Hall's [18] call from 10 years ago for fundamental change in thinking and action on the sustainability of tourism remains relevant today. Hall [18] noted the importance of including the maintenance of the natural capital and steady-state thinking. Author [18] points out that in another way tourism will remain unsustainable, and we will not solve the problem of overtourism completely. Therefore, we should rethink our understanding of tourism using a distinctive approach to tourism development $[18,19,78]$, involving community based tourism, responsible tourism, slow tourism, and staycations.

Overtourism and sustainable tourism as important contexts influence the changing meaning of the right to travel and the right to live. On the one hand, the overtourism context influences and make more heard the voices of residents, while on the other hand the sustainable tourism context influences the right to travel, asking tourist voices to become more responsible for the locality. Both of these rights pose a serious threat, not only to conflicts between the right to travel and the right to reside, or between community autonomy and personal freedom, but also the regulation and enforcement of locals' rights and the protection of the public interest.

\section{Concluding Insights}

The integrative review analysis, representing different scientific and legal sources, showed that overtourism as a term has been intensively used for less than 2 years, however the problem itself in the scientific world is not new and has been discussed over the last 30 years. In recent years, more and more world tourist destinations have been dealing with this challenging phenomenon.

The relationship between the rights of travelers and the local population's right to live where they please is closely related to the concept of freedom of movement in the context of overtourism. After analysis of legal acts related to the rights of travelers and the residents' rights in the context of overtourism, it can be noted that the rights of travelers are clearer and better protected, and the interpretation of the rights of the local population is too broad and not as effectively expressed. As for the legal relationship between the traveler and the local resident living in an epicenter of overtourism, it is important to conclude that overtourism is associated with the fact that the rights of travelers, who are tourists moving for entertainment and consumption purposes, are not equivalent to the residents' rights-local residents and those people who have changed their place of residence.

This interdisciplinary discussion on overtourism has shown the importance of rethinking the concept of sustainability in tourism as a holistic principle of democracy, and as a degrowth movement. This integrative review suggests possible insights for solving the problem of overtourism by working 
together and by striving to develop sustainable tourism goals, thus balancing the right to travel and the residents' rights. Further research should be directed towards improving the legal situation of residents. As the presented integrative review paper is a preliminary work, there is a need for further research in order to find possible concrete solutions for overtourism.

Author Contributions: Data collection: R.P. and D.P.; Methodology: R.P. and D.P.; Visualization: R.P. and D.P.; Writing —original draft: D.P. and R.P.; Writing—review editing: D.P;; and R.P.

Funding: This research received no external funding.

Acknowledgments: We would like to thank to the comments of three anonymous referees and editor Hank Liu for their engagement with and contributions to this article.

Conflicts of Interest: The authors declare no conflict of interest.

\section{References}

1. World Tourism Organization (UNWTO). 'Overtourism'?-Understanding and Managing Urban Tourism Growth beyond Perceptions; UNWTO: Madrid, Spain, 2018.

2. Heslinga, J.H. Synergetic Tourism-Landscape Interactions: Policy, Public Discourse and Partnerships; University of Groningen: Groningen, The Netherlands, 2018.

3. Tolkach, D.; Pratt, S.; Zeng, C.Y.H. Ethics of Chinese \& Western tourists in Hong Kong. Ann. Tour. Res. 2017, 63, 83-96.

4. Nagy, A. The Impact of Tourism on the Development of Spatial Economy of Hungary; Szent István University: Gödöllő, Hungary, 2016; pp. 65-76.

5. Williams, J.; Lawson, R. Community issues and resident opinions of tourism. Ann. Tour. Res. 2001, 28, 22-28. [CrossRef]

6. Margaryan, L. Commercialization of Nature through Tourism; Mid Sweden University: Östersund, Sweden, 2017; pp. 78-83.

7. Ram, Y.; Hall, C.M. Walking tourism in cities: Introducing the special issue. Int. J. Tour. Cities 2018, 3, 281-284. [CrossRef]

8. Andriotis, K. Tourism development and the degrowth paradigm. In Proceedings of the 2nd Belgrade International Tourism Conference (BITCO 2014) Thematic Tourism in a Global Environment: Advantages, Challenges and Future Developments, Belgrade, Serbia, 27-29 March 2014; pp. 37-45.

9. Buhr, K.; Isaksson, K.; Hagbert, P. Local Interpretations of Degrowth-Actors, Arenas and Attempts to Influence Policy. Sustainability 2018, 10, 1899. [CrossRef]

10. Juss, S.S. Free Movement and the World Order. Int. J. Refug. Law 2004, 16, 289-335. [CrossRef]

11. Dauvergne, C. Sovereignty, Migration and the Rule of Law in Global Times. Mod. Law Rev. 2004, 67, 125-138. [CrossRef]

12. Gilbert, J. Nomadic Peoples and Human Rights; University of East London: London, UK, 2014; pp. 109-115.

13. Torraco, R.J. Writing Integrative Literature Reviews: Using the Past and Present to Explore the Future. Hum. Resour. Dev. Rev. 2016, 15, 404-428. [CrossRef]

14. Whittemore, R.; Knafl, K. The integrative review: Updated methodology. J. Adv. Nurs. 2005, 52, 546-553. [CrossRef] [PubMed]

15. Alvarez-Sousa, A. The Problems of Tourist Sustainability in Cultural Cities: Socio-Political Perceptions and Interests Management. Sustainability 2018, 10, 503. [CrossRef]

16. Gössling, S.; Scott, D.; Hall, C.M. Global trends in length of stay: Implications for destination management and climate change. J. Sustain. Tour. 2018, 26, 138-149. [CrossRef]

17. Davidson, K.M.; Kellett, J.; Wilson, L.; Pullen, S. Assessing urban sustainability from a social democratic perspective: A thematic approach. Local Environ. 2012, 17, 57-73. [CrossRef]

18. Hall, C.M. Changing paradigms and global change: From sustainable to steady-state tourism. Tour. Recreat. Res. 2010, 35, 131-143. [CrossRef]

19. Hall, C.M. Degrowing tourism: Décroissance, sustainable consumption and steady-state tourism. Anatolia 2009, 20, 46-61. [CrossRef]

20. Flipo, F.; Schneider, F. Proceedings of the First International Conference on Economic De-Growth for Ecological Sustainability and Social Equity; Degrowth Conference: Paris, France, 2008. 
21. Armenski, T.; Pavluković, V.; Pejović, L.; Lukić, T.; Djurdjev, B. Interaction between Tourists and Residents: Influence on Tourism Development. Pol. Soc. Rev. 2011, 173, 107-118.

22. Brokaj, R. Local government's role in the sustainable tourism development of a destination. Eur. Sci. J. 2014, 31, 87-99.

23. Kim, J.Y. The Reality of Encounters with Local Life in Other Cultures. Sustainability 2018, 10, 27. [CrossRef]

24. Oklevik, O.; Gössling, S.; Hall, C.M.; Jacobsen Steen, J.K.; Grøtte, I.P.; McCabe, S. Overtourism, optimisation, and destination performance indicators: A case study of activities in Fjord Norway. J. Sustain. Tour. 2019. [CrossRef]

25. Séraphina, H.; Zamanb, M.; Olverc, S.; Bourliataux-Lajoinied, S.; Dosquete, F. Destination branding and overtourism. J. Hosp. Tour. Manag. 2019, 38, 1-4. [CrossRef]

26. Milano, C. Overtourism, social unrest and tourismphobia. A controversial debate. PASOS Rev. Tur. Patrim. Cult. 2018, 16, 551-564. [CrossRef]

27. Blanco-Romero, A.; Blázquez-Salom, M.; Cànoves, G. Barcelona, Housing Rent Bubble in a Tourist City. Social Responses and Local Policies. Sustainability 2018, 10, 2043. [CrossRef]

28. Martín, J.M.; Guaita Martínez, J.M.; Salinas Fernández, J.A. An Analysis of the Factors behind the Citizen's Attitude of Rejection towards Tourism in a Context of Overtourism and Economic Dependence on This Activity. Sustainability 2018, 10, 2851. [CrossRef]

29. Postma, A.; Schmuecker, D. Understanding and overcoming negative impacts of tourism in city destinations: Conceptual model and strategic framework. J. Tour. Futures 2017, 3, 144-156. [CrossRef]

30. Muler Gonzalez, V.; Coromina, L.; Galí, N. Overtourism: Residents' perceptions of tourism impact as an indicator of resident social carrying capacity-Case study of a Spanish heritage town. Tour. Rev. 2018, 73, 277-296. [CrossRef]

31. Papathanassis, A. Over-Tourism and Anti-Tourist Sentiment: An Exploratory Analysis and Discussion. Ovidius" University Annals. Econ. Sci. Ser. 2017, 17, 288-293.

32. Bonnie, K. Why is there no right to live where you please? In The Week; Dennis Publishing: London, UK, 2018.

33. Kim, S. Iceland Now Has Seven Times More Tourists than Locals-But Which Country Is Most Overrun with Visitors? The Telegraph. 2017. Available online: https://www.telegraph.co.uk/travel/destinations/ europe/iceland/articles/tourists-outnumber-locals-in-iceland (accessed on 12 January 2019).

34. Mack, C. Responsible Travel. Who Is Responsible Overtourism? 2018. Available online: https://www. responsibletravel.com/copy/who-is-responsible-for-overtourism (accessed on 26 January 2019).

35. Scott, A. How Social Media Influencers Can Use Their Power to Combat Overtourism. 2018. Available online: https: / / uncorneredmarket.com/overtourism-social-media-influencers-power (accessed on 12 January 2019).

36. Koens, K.; Postma, A.; Papp, B. Understanding 'overtourism' in a city context. Sustainability 2018, 10, 4384. [CrossRef]

37. Erschbamer, G.; Innerhofer, E.; Pechlaner, H. Overtourism: How Much Tourism is Too Much; Eurac Research: Bolzano, Italy, 2018.

38. Canestrelli, E.; Costa, P. Tourist Carrying Capacity. A Fuzzy Approach. Ann. Tour. Res. 1991, 18, $295-311$. [CrossRef]

39. Page, S. Urban Tourism; Routledge: London, UK, 1995.

40. Borg, J.; Costa, P.; Gotti, G. Tourism in European heritage cities. Ann. Tour. Res. 1996, 23, 306-321. [CrossRef]

41. Higgins-Desbiolles, F. Sustainable tourism: Sustaining tourism or something more? Tour. Manag. Perspect. 2018, 25, 157-160. [CrossRef]

42. Marcuse, P. From critical urban theory to the right to the city. City 2009, 13, 185-197. [CrossRef]

43. Hall, C.M. A typology of governance and its implications for tourism policy analysis. J. Sustain. Tour. 2011, 19, 437-457. [CrossRef]

44. Freytag, T.; Bauder, M. Bottom-up touristification and urban transformations in Paris. Tour. Geogr. 2018, 20, 443-460. [CrossRef]

45. Shoval, N. Urban planning and tourism in European cities. Tour. Geogr. 2018, 20, 371-376. [CrossRef]

46. Smith, M.K.; Egedy, T.; Csizmady, A.; Jancsik, A.; Olt, G.; Michalkó, G. Non-planning and tourism consumption in Budapest's inner city. Tour. Geogr. 2018, 20, 524-528. [CrossRef]

47. Postma, A. When the Tourists Flew in: Critical Encounters in the Development of Tourism; University of Groningen: Groningen, The Netherlands, 2013; pp. 45-58. 
48. Responsible Tourism (n.d.), over Tourism. Available online: www.responsibletourismpartnership.org/ overtourism (accessed on 10 February 2019).

49. Goodwin, H. The Challenge of Overtourism. Responsible Tourism Partnership Working Paper 4. 2017. Available online: https://haroldgoodwin.info/pubs/RTP \T1 \textquoterightWP4Overtourism01 T1 \textquoteright2017.pdf (accessed on 12 January 2019).

50. Groenendijk, K.; Guild, E.; Carrera, S. Illiberal Liberal States: Immigration, Citizenship and Integration in the EU; Centre for European Policy Studies: Brussels, Belgium, 2013; pp. 87-98.

51. USA Supreme Court Case Kent v. Dulles, 357 U.S. 116. 1958. Available online: https://supreme.justia.com/ cases/federal/us/357/116/ (accessed on 17 January 2019).

52. Case Loubna El Ghar v. Socialist People's Libyan Arab Jamahiriya, No. 1107. 2002. Available online: https: / / www.refworld.org/cases,HRC,421f00256.html (accessed on 2 February 2019).

53. Case Samuel Lichtensztejn v. Uruguay, No. 77. 1980. Available online: http://hrlibrary.umn.edu/undocs/ newscans /77-1980.html (accessed on 7 February 2019).

54. Case Timishev v. Russia, No. 55762/00 and 55974/00. 2005. Available online: https://minorityrights.org/ law-and-legal-cases / timishev-v-russia-2/ (accessed on 7 February 2019).

55. Case Karpacheva and Karpachev v. Russia, No. 34861/04. 2011. Available online: http://www. antoniocasella.eu/archica/ECHR_12feb15.pdf (accessed on 12 February 2019).

56. Case Lauri Peltonen v. Finland, Paras, No. 492/1992. Available online: http://hrlibrary.umn.edu/undocs/ html/vws492.htm (accessed on 12 February 2019).

57. Case Stamose v. Bulgaria, No. 29713/05. 2012. Available online: https://lovdata.no/static/EMDN/emd2005-029713.pdf (accessed on 12 February 2019).

58. Case Coeriel and Aurik v. The Netherlands, No. 453/1991. 1994. Available online: http://hrlibrary.umn.edu/ undocs/html/vws453.htm (accessed on 15 February 2019).

59. Case Niemitz v. Germany, No. 13710/88. 1992. Available online: https://www.refworld.org/cases,ECHR, 3f32560b4.html (accessed on 15 February 2019).

60. Convention on the Rights of the Child, Adopted and Opened for Signature, Ratification and Accession by G.A. Res. 44/25 of 20 Nov. 1989, Entered into Force 2 September 1990, in Accordance with Article 49, Art. 10. Available online: http:/ / www.ohchr.org/english/law/crchtm (accessed on 16 January 2019).

61. International Covenant on Civil and Political Rights (ICCPR), Adopted and Opened for Signature, Ratification and Accession by G.A. Res. 2200A (XXI) of 16 December 1966, Entered into Force 23 March 1976, in Accordance with Article 49, Art. 12. Available online: http:/ /www.ohchr.org/english/law/ccpr.htm (accessed on 12 January 2019).

62. International Convention on the Protection of the Rights of All Migrant Workers and Members of Their Families (ICPMW). Available online: https:/ / www.ohchr.org/en/professionalinterest/pages/cmw.aspx (accessed on 12 January 2019).

63. United Nations General Assembly Session 61 Resolution 106. Convention on the Rights of Persons with Disabilities A/RES/61/106. 13 December 2006. Available online: https:/ /www.un.org/en/development/desa/ population/migration/generalassembly/docs/globalcompact/A_RES_61_106.pdf (accessed on 12 January 2019).

64. Lithuanian Republic Constitution. Lithuanian People Accepted in the Referendum in 1992 at the $25 \mathrm{~d}$. of October. State News. 1992, (33-1014). Available online: http://www3.lrs.lt/home/Konstitucija/ Constitution.htm (accessed on 12 January 2019).

65. Universal Declaration of Human Rights, Adopted and Proclaimed by G.A. Res. 217 A (III) of 10 December 1948, Art. 13. Available online: http:/ / www.unhchr.ch/udhr/langleng.htm (accessed on 24 January 2019).

66. USA Case Palko v. Connecticut, 302 U.S. 319, 324-325. 1937. Available online: https://supreme.justia.com/ cases/federal/us/302/319/ (accessed on 12 January 2019).

67. USA Case Regents of the Univ. of Cal. v. Bakke, 438 U.S. 265, 357. 1977. Available online: https:/ / supreme. justia.com/cases/federal/us/438/265/ (accessed on 12 January 2019).

68. Bodirsky, K. Between equal rights force decides? City 2017, 21, 672-681. [CrossRef]

69. Darcy, M.; Rogers, D. Inhabitance, place-making and the right to the city: Public housing redevelopment in Sydney. Int. J. Hous. Policy 2014, 14, 236-256. [CrossRef]

70. Domaradzka, A. Urban Social Movements and the Right to the City: An Introduction to the Special Issue on Urban Mobilization. Volunt. Int. J. Volunt. Nonprofit Org. 2018, 29, 607-620. [CrossRef] 
71. Boer, R.W.J.; de Vries, J. The right to the city as a tool for urban social movements: The case of Barceloneta. In Proceedings of the 4th International Conference of the International Forum on Urbanism (IFoU), Delft, The Netherlands, 26-28 November 2009.

72. Postma, A.; Spruyt, E.; Cavagnaro, E. Sustainable Tourism 2040: A Manifesto; European Tourism Futures Institute: Leeuwarden, The Netherlands, 2013; pp. 89-96.

73. Cernat, L.; Gourdon, J. Is the Concept of Sustainable Tourism Sustainable; UN: New York, NY, YSA, 2007; pp. 89-95.

74. Swarbrooke, J. Sustainable Tourism Management; Cabi Publishing: Oxon, UK, 2005; pp. 75-82.

75. Büscher, B.; Fletcher, R. Destructive Creation: Capital Accumulation and the Structural Violence of Tourism. J. Sustain. Tour. 2017, 25, 651-667. [CrossRef]

76. Waller, I. Permanent Tourism and Host-Guest Relations: An Empirical Study of UK Tourist-Migrants in Didim, Turkey; University of Central Lancashire: Lancaster, UK, 2018; pp. 48-57.

77. Kallis, G. In defence of degrowth. Ecol. Econ. 2011, 70, 873-880. [CrossRef]

78. Andriotis, K. Degrowth in Tourism: Conceptual, Theoretical and Philosophical Issues; CABI: Wallingford, UK, 2018.

(C) 2019 by the authors. Licensee MDPI, Basel, Switzerland. This article is an open access article distributed under the terms and conditions of the Creative Commons Attribution (CC BY) license (http:/ / creativecommons.org/licenses/by/4.0/). 